\title{
Removal of uterine fibroids by mini-laparotomy technique in women who wish to preserve their uterus and fertility
}

\author{
Kinga Księżakowska-Łakoma ${ }^{1}$, Monika Żyła ${ }^{1}$, Jacek Wilczyński ${ }^{2}$ \\ ${ }^{1}$ Department of Gynecology, Chair of Obstetrics and Gynecological Surgery, Medical University of Lodz, Lodz, Poland \\ ${ }^{2}$ Department of Gynecology, Polish Mother's Memorial Hospital - Research Institute, Lodz, Poland
}

Videosurgery Miniinv 2015; 10 (4): 561-566 DOI: $10.5114 /$ wiitm.2015.56998

\begin{abstract}
Introduction: The minilaparotomy is considered to be a safe and effective alternative to laparoscopy and abdominal laparotomy in myomectomy cases.

Aim: To perform a retrospective analysis of pre-surgical assessment, surgical course and post-operational parameters in women wishing to preserve their uterus and fertility who underwent myomectomy by minilaparotomy in the Department of Gynecology and Gynecological Oncology at the Polish Mother's Memorial Hospital - Research Institute in Lodz in the years 2008-2014.

Material and methods: A total of 76 patients were qualified for minilaparotomy due to a benign gynecological pathology. Only 21 patients with uterine fibroids who wanted to preserve their uterus and fertility were appropriate for this study. Patients' records were analyzed in terms of: epidemiological history, surgical course, postoperative stay and pathological data. All studied patients were asked in 2014 about conception and pregnancy after minilaparotomy. Results: The median age was 35.7 years. The median patient body mass index (BMI) was $24 \mathrm{~kg} / \mathrm{m}^{2}$. The average decrease of hemoglobin was $1.5 \mathrm{~g} / \mathrm{dl}$. The size of the myoma was between 1.5 and $15 \mathrm{~cm}$. There were no serious post-surgical complications. The size of the myoma did not correlate significantly with operation time, BMI or blood loss. There was no statistically significant dependence between operation time and average hematocrit and hemoglobin decrease. In our group 7 patients who had undergone myomectomy tried to achieve conception. Four of them succeeded in pregnancy and gave birth to healthy infants.

Conclusions: Myomectomy performed via minilaparotomy is a safe procedure for patients willing to preserve their uterus and fertility, and it combines some advantages of both laparotomy and laparoscopy.
\end{abstract}

Key words: infertility, uterine myomas, fertility, minilaparotomy.

\section{Introduction}

Uterine fibroids are the most common estrogen-dependent uterine benign tumors in women. They are present 3 times more often in females whose first-degree relative suffered from fibroids, indicating the existence of some genetic predisposition, and are more frequently diagnosed in nulliparous, obese women [1-3]. About $3-10 \%$ of fibroids appear in reproductive age and could distort the uterine cavity and change uterine contractility, provoking profound menstrual and/or inter-menstrual bleeding. They could also be risk factors for decreased fertility or even infertility, and in the group of infertile women uterine fibroids are diagnosed in up to $2.5 \%$ of cases $[4,5]$. The probable reasons for their adverse action are: endometritis localized in the uterine wall adjacent to myoma, negative effect on embryo implantation, as well as disturbance in 
spermatozoa and oocyte migration $[6,7]$. The risk of miscarriage, premature delivery and placental abruption is more frequent in the group of patients with fibroids. Therefore, many authors claim that large (over $5 \mathrm{~cm}$ in diameter, single and multiple) fibroids, especially when distorting the uterine cavity, should be removed in reproductive age women who are planning, or according to their age, may potentially plan reproduction in the future. That is even more true for women who suffered from miscarriages or unexplained infertility [8-13].

Noninvasive uterine artery embolization does not apply to women who wish their fertility to be preserved, as this method compared with surgical myomectomy increases the risk of miscarriage, premature delivery, intrauterine growth restriction, and postpartum hemorrhage [14-18]. The recommended treatment in reproductive age women is abdominal laparotomy or laparoscopic myomectomy. The choice of surgical technique depends on tumor size, surgeon experience and the patient preferences [19]. Laparoscopy has many advantages including shorter hospital stay, lower intensity of pain, fast recovery and cosmetic effect [20-24]. However, the main disadvantages include the total surgery duration, increased blood loss and high risk of conversion to laparotomy, especially in the case of fibroids of greater diameter or excessive bleeding [20-22]. Moreover, after laparoscopic myomectomy an increased risk of uterine wall damage during pregnancy has been reported [25-27]. In the opinion of some authors, minilaparotomy could be a way to combine the advantages and minimally invasive potential of laparoscopy with the easy access gained by laparotomy [28-36].

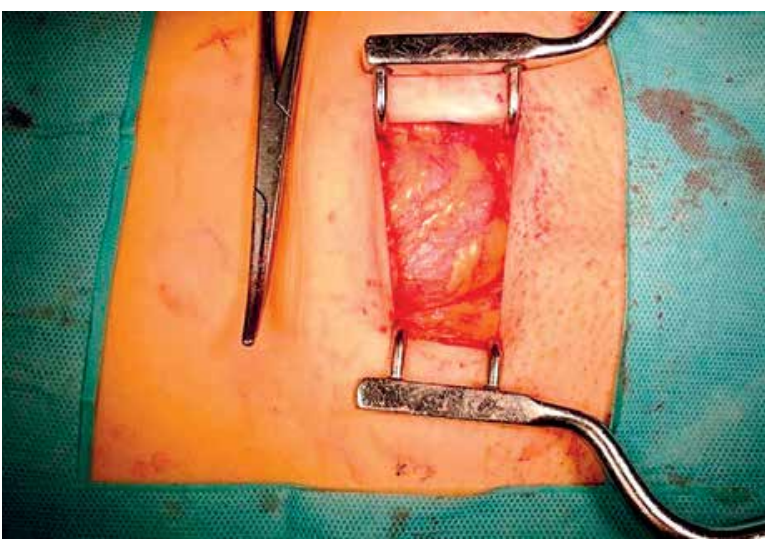

Photo 1. Size of abdominal wall incision

\section{Aim}

The aim of the study was to perform a retrospective analysis of pre-surgical assessment, surgical course and post-operational parameters in women wishing to preserve their uterus and fertility, who underwent myomectomy by minilaparotomy.

\section{Material and methods}

A total of 76 patients were qualified for minilaparotomy due to benign gynecological pathology in the Department of Gynecology and Gynecological Oncology, Polish Mother's Memorial Hospital - Research Institute between 2008 and 2014. Only patients with uterine fibroids, who wanted to preserve their uterus and fertility, were appropriate for this study. Patients' records were analyzed in terms of: epidemiological history (age, body mass index (BMI), medical and obstetrical history), surgical course (operation time, hemoglobin drop, type of anesthesia), postoperative stay (duration, use of analgesics and antibiotics, complications) and pathological data (number, size and localization of fibroids). All studied patients were asked in 2014 about conception and pregnancy after minilaparotomy.

\section{Surgical technique}

The skin incision of 4-6 cm length was done crosswise suprapubically about 2-3 cm over the upper edge of the pubic symphysis (Photo 1). Next, using monopolar cutting and coagulation, adipose tissue was dissected thoroughly crosswise until the anterior surface of abdominal fascia was unveiled. Then, using coagulation, the anterior surface of the abdominal fascia was unsheathed from the adipose tissue in the umbilical direction while the overlying skin was pushed up using the retractors. In the next move, the fascia was cut longitudinally at the length of $6-8 \mathrm{~cm}$ from the pubic symphysis towards the umbilicus. The rectus muscles were spread laterally, the peritoneal membrane was opened longitudinally, an automatic retractor was placed inside the wound, and the intestines were pushed back from the surgical site with surgical drapes. The longer mid-sagittal incision enabled a sufficient view into the peritoneal cavity, while the perpendicular cutaneous incision was small enough to provide a proper cosmetic effect. A diamond-shaped access to the operative site was gained, and a considerable part of the uterus was visible. In the case of a large lesion, adrenalin 
solution was injected into surrounding tissue in order to decrease bleeding. After the fibroid was located, it was grasped and cut off from the uterine trunk with monopolar coagulation, while being simultaneously pulled through the wound in an upward direction. Using this technique enabled the gradual removal even of fibroids of a diameter exceeding the wound dimensions. Moreover, an operator had a possibility to control visually and by palpation the position of the myoma in relation to the uterine cavity, which, in most cases, protected against its accidental opening. In the event that the uterine cavity was opened, a no. 16 Redon drain was placed inside the uterine cavity and its walls were reconstructed. After removal of the fibroid, the uterus was sutured with layered sutures. The parietal peritoneum was not sutured, and continuous sutures were adopted for the fascia and skin.

\section{Statistical analysis}

Statistical analysis was performed using the Statistica 10.0 (StatSoft, Inc., Tulsa, OK, USA) software package. Conformity with a normal distribution of quantitative data was checked using the Shapiro-Wilk $W$ test. The Mann-Whitney $U$ test and the Spearman rank correlation coefficient were employed to verify the dependences between selected variables. A $p$-value $<0.05$ was assumed significant in all tests conducted.

\section{Results}

The median age was 35.7 years (min. 27 years old, 43 years old). The median patient BMI was 24 (range: 19.4-32.1) kg/m². Seven patients with uterine fibroids had a history of hypothyroidism, arterial hypertension, mitral valve prolapse, venous varices or asthma. Seven patients reported a history of previous abdominal surgery (appendectomy, cesarean section, removal of ectopic pregnancy, removal of teratoma).

In this study, nulliparous women were in the majority (14 patients, 66.7\%). In our group, 7 (33.3\%) patients who had undergone myomectomy tried to achieve conception. Four of them (pregnancy rate $57.1 \%)$, succeeded in pregnancy and gave birth to healthy infants. In 3 (75\%) patients, cesarean section was performed.

In the case of 16 (76.2\%) patients, spinal anesthesia was performed, while in the remaining 5 (23.8\%) patients, general anesthesia was used. After surgery,

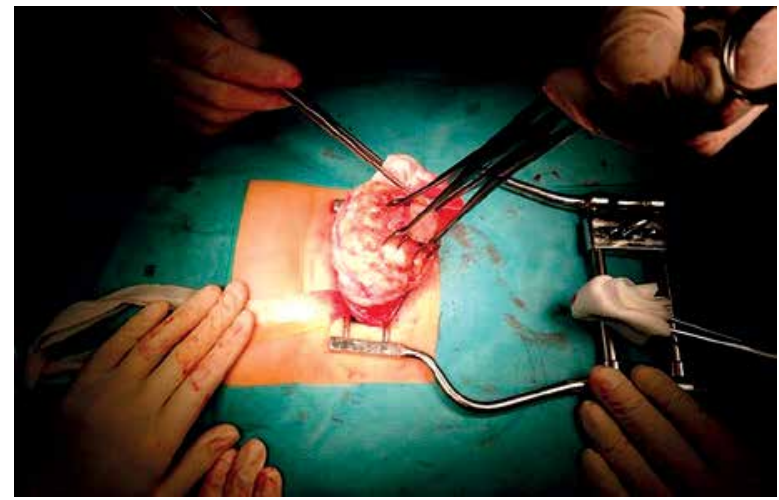

Photo 2. Intramural type of myoma uteri

analgesics were administered in each patient. The mean duration of analgesics administration was 3.8 days (min. 2 days, max. 10 days). In 5 women, antibiotics were given. Average duration of hospitalization was 4.2 days (min. 2 days, max. 10 days).

The size of the myoma (in the case of numerous fibroids, the size of the largest) was between 1.5 and $15 \mathrm{~cm}$ (mean: $7.2 \mathrm{~cm}$ ). The intramural type of fibroids was most prevalent (Photo 2). One patient had a submucosal myoma. In 2 (9.5\%) cases, during removal of fibroids of $15 \mathrm{~cm}$ and $4 \mathrm{~cm}$ diameter, the uterine cavity was opened. One of the patients underwent left salpingectomy due to removal of a large myoma located in the uterine horn.

The average operative time was $67.6 \mathrm{~min}$ (from 45 to 90 min). There were no serious post-surgical complications.

In the investigated patients, the average decrease of hemoglobin concentration was $1.5 \mathrm{~g} / \mathrm{dl}$ (min. $-0.3 \mathrm{~g} / \mathrm{dl}$, max. $3.6 \mathrm{~g} / \mathrm{dl}$ ) and the average hematocrit (Hct) decrease was $4.1 \%$ (min. $-0.6 \%$, max. 10.8\%). In 18 patients, a drainage tube was applied and the volume of collected fluid averaged $218 \mathrm{ml}$ (min. $20 \mathrm{ml}$, $\max .450 \mathrm{ml}$ ).

We did not observe a statistically significant difference of tumor size between nullipara and multipara. Similarly, the size of the myoma did not correlate significantly with other tested parameters such as operation time, BMI or blood loss. There was no statistically significant dependence between the operation time and the average Hct and hemoglobin (Hgb) decrease (Table I).

\section{Discussion}

Despite the fact that in some of our patients not the restoration of fertility but rather preservation 
Table I. Surgical parameters and pathological data following myomectomy by minilaparotomy

\begin{tabular}{|c|c|c|c|c|c|c|c|}
\hline Patient & $\begin{array}{l}\text { Operation } \\
\text { time [min] }\end{array}$ & $\begin{array}{l}\text { HGB drop } \\
{[\mathrm{g} / \mathrm{dl}]}\end{array}$ & $\begin{array}{l}\text { Hospital } \\
\text { stay [days] }\end{array}$ & $\begin{array}{c}\text { Total number } \\
\text { of fibroids }\end{array}$ & $\begin{array}{l}\text { Size of largest } \\
\text { fibroid [cm] }\end{array}$ & $\begin{array}{l}\text { Localization } \\
\text { of fibroids }\end{array}$ & Complications \\
\hline 1 & 50 & 0.6 & 3 & 2 & 5 & Intramural & No \\
\hline 2 & 60 & 0.3 & 6 & 1 & 10 & Intramural & No \\
\hline 3 & 65 & - & 5 & 1 & 1.5 & Intramural & No \\
\hline 4 & 50 & - & 5 & 1 & 5 & Intramural & No \\
\hline 5 & 60 & 0.8 & 4 & 2 & 7 & Pedunculated & No \\
\hline 6 & 70 & 1.8 & 3 & 2 & 10 & Intramural & No \\
\hline 7 & 90 & 1.8 & 3 & 1 & 15 & Intramural & $\begin{array}{c}\text { Opening } \\
\text { of uterine cavity }\end{array}$ \\
\hline 8 & 75 & - & 6 & 1 & 10 & Intramural & No \\
\hline 9 & 45 & 2.4 & 3 & 1 & 4 & Intramural & No \\
\hline 10 & 90 & 2.5 & 4 & 1 & 3 & Pedunculated & No \\
\hline 11 & 70 & 1.5 & 4 & 1 & 8 & Intramural & No \\
\hline 12 & 75 & 0.7 & 4 & 3 & 6 & Intramural & No \\
\hline 13 & 70 & 3.6 & 4 & 3 & 4 & $\begin{array}{l}\text { Intramural and } \\
\text { pedunculated }\end{array}$ & No \\
\hline 14 & 80 & - & 10 & 7 & 8 & Intramural & No \\
\hline 15 & 60 & - & 3 & 1 & 10 & Pedunculated & No \\
\hline 16 & 65 & 0.6 & 3 & 1 & 6 & Intramural & No \\
\hline 17 & 70 & 2.0 & 4 & 2 & 5 & Submucosal & No \\
\hline 18 & 65 & 1.6 & 4 & 1 & 5 & Intramural & No \\
\hline 19 & 70 & - & 3 & 1 & 4 & Intramural & $\begin{array}{c}\text { Opening } \\
\text { of uterine cavity }\end{array}$ \\
\hline 20 & 80 & - & 4 & 1 & 10 & Intramural & No \\
\hline 21 & 60 & - & 4 & 1 & 9 & Intramural & No \\
\hline
\end{tabular}

(-) No information.

of the uterus was the main goal, we were obliged to take into consideration their reproductive future. Therefore, the procedures were performed as in the infertile women. Infertility occurs in $27 \%$ of women with uterine fibroids, and myomectomy is performed in $2.4 \%$ of infertile women, where the only probable cause of infertility is myoma [37]. In our group, $7(33.3 \%)$ patients who had undergone myomectomy tried to achieve conception. Four of them (pregnancy rate $57.1 \%$ ) succeeded in pregnancy and gave birth to healthy infants. Two patients became pregnant 1 year after myomectomy, the others 3 years after surgery. In 3 (75\%) patients, cesarean section was performed. In the study of Seracchioli et al. [21], who assessed obstetric outcome after transabdominal myomectomy in a group of 65 patients, of 59 patients who tried to become pregnant, 33 were successful (pregnancy rate 55.9\%), and cesarean section was performed in 21 (63.6\%) patients. Bernardi et al. [38] reported recently that the conception rate after laparoscopic myomectomy was 68\%, with a lower miscarriage rate after surgery. Cesarean section was performed in $46 \%$ of patients.

Like other authors, in choosing the operational technique we considered the size and number of fibroids, their localization, surgical history indicative of probable technical obstacles (e.g. severe adhesions), and finally the patient's preference $[32,34$, 36, 39]. In women who wish to preserve their uterus and fertility, the surgical technique should take into consideration that palpation of the uterine body enables more precise identification of the position of intramural fibroids and their possible conflict with the uterine cavity. In the opinion of some authors, 
this is an advantage of minilaparotomy over laparoscopy. Moreover, minilaparotomy should enable better uterus reconstruction in the case of a large myoma, and in the case of increased bleeding compared with laparoscopy it allows quicker and more accurate hemostasis [34]. In the majority of reports, the authors performed minilaparotomy under subarachnoid anesthesia, and this was also the case in $76.2 \%$ of our patients. The average operative time was $67.6 \mathrm{~min}$, which is a result similar to that described in other studies, but much shorter compared to ordinary laparotomy or laparoscopy [20,36, $39,40]$.

The intraoperative blood loss estimated on the basis of both hemoglobin and hematocrit drop after the surgery was $1.5 \mathrm{~g} / \mathrm{dl}$ and $4.1 \%$ respectively. Almost identical values were reported by Malinowski et al. [36] in their study devoted to use of minilaparotomy in benign gynecological diseases. Cagnacci et al. [20] in their group of patients subjected to myomectomy by minilaparotomy reported an average decrease of hemoglobin of $3.07 \mathrm{~g} / \mathrm{dl}$, which is twice as large as in our study, despite the fact that the maximal diameter of removed fibroid in their study was only $6.8 \mathrm{~cm}$. Probably, the use of monopolar cut and coagulation as well as adrenaline injection performed during our procedures accounts for these differences. According to Tinelli et al. [41], laparoscopic myomectomy is characterized by less intra- and post-surgical blood loss compared to laparotomy.

We did not observe statistically significant difference of tumor size between nullipara and multipara. Similarly, myoma size did not correlate significantly with other tested parameters such as operation time or blood loss. Other authors have pointed out that the dimensions of fibroid could determine indications for the type of surgery and its range. At least a $5 \mathrm{~cm}$ long incision is recommended if the myoma is $9 \mathrm{~cm}$ in diameter [34]. Laparoscopic myomectomy is recommended when the myoma does not exceed $9 \mathrm{~cm}$ in diameter or the number of fibroids is not more than 2-3. Otherwise, the risk of conversion to laparotomy is higher [42]. All patients underwent intraoperative prophylactic antibiotic therapy, but only 5 (23.8\%) patients were administered antibiotic treatment due to increased leukocytosis and anemia. Similarly, Seracchioli et al. [21] carried out antibiotic prophylaxis in all patients before transabdominal myomectomy and in $26 \%$ of patients with a febrile state of more than $38^{\circ} \mathrm{C}$. We did not observe any serious complications and no cases of reoperations were noted. The same was true in the study of Malinowski et al. [36]. Other authors have reported that serious complications such as excessive bleeding, paralytic ileus, urinary tract infection, wound infection, and repeat laparotomy procedures were rare and less frequent after minilaparotomy compared to normal laparotomy [43]. The average hospital stay was 4.2 days. In other studies, the average time to discharge after surgery was 1-3.7 days [28, 44, 45].

\section{Conclusions}

We conclude that myomectomy performed via minilaparotomy is a safe procedure for patients willing to preserve their uterus and fertility, and it combines some advantages of both laparotomy and laparoscopy.

\section{Conflict of interest}

The authors declare no conflict of interest.

\section{References}

1. Blake RE. Leiomyomata uteri: hormonal and molecular determinants of growth. J Natl Med Assoc 2007; 99: 1170-88.

2. Lumbiganon P, Rugpao S, Phandhu-fung S, et al. Protective effect of depot-medroxyprogesterone acetate on surgically treated uterine leiomyomas: a multicentre case-control study. $\mathrm{Br}$ J Obstet Gynaecol 1996; 103: 909-14.

3. Vikhlyaeva EM, Khodzhaeva ZS, Fantschenko ND. Familial predisposition to uterine leiomyomas. Int J Gynecol Obstet 1995; 51: $127-31$.

4. Laughlin SK, Baird DD, Savitz DA, et al. Prevalence of uterine leiomyomas in the first trimester of pregnancy: an ultrasound-screening study. Obstet Gynecol 2009; 113: 630-5.

5. Verkauf BS. Myomectomy for fertility enhancement and preservation. Fertil Steril 1992; 58: 1-15.

6. Richards PA, Richards PD, Tiltman AJ. The ultrastructure of fibromyomatous myometrium and its relationship to infertility. Hum Reprod Update 1998; 4: 520-5.

7. Somigliana E, Vercellini P, Daguati R, et al. Fibroids and female reproduction: a critical analysis of the evidence. Hum Reprod Update 2007; 13: 465-76.

8. Miller AWF, Hanretty KP. Ciąża mnoga, ciąża wysokiego ryzyka. In: Położnictwo ilustrowane. Miller AWF (ed.). Libramed, Warsaw 2000; 193-221.

9. Pisarska-Krawczyk M, Spaczyński M, Pisarski T. Nowotwory u kobiety ciężarnej. In: Położnictwo i ginekologia. Pisarski T (ed.). Wyd Lek PZWL, Warsaw 2001; 520-8.

10. Słomko Z, Wolna M, Bręborowicz J, Spaczyński M. Problemy onkologiczne w okresie okołoporodowym. In: Medycyna perinatalna. Słomko Z (ed.). Wyd Lek PZWL, Warsaw 1994; Suppl.: 267-307. 
11. Strauss G. Trzon macicy. In: Ginekologia praktyczna. Pschyrembel W, Strauss G, Petri E (ed.). Wyd Lek PZWL, Warsaw 1994; 181-251.

12. Taylor E, Gomel V. The uterus and fertility. Fertil Steril 2008; 89: 1-16.

13. Saravelos SH, Yan J, Rehmani H, et al. The prevalence and impact of fibroids and their treatment on the outcome of pregnancy in women with recurrent miscarriage. Hum Reprod 2011; 26: 3274-9.

14. Agdi M, Tulandi T. Endoscopic management of uterine fibroids. Best Pract Res Clin Obstet Gynaecol 2008; 22: 707-16.

15. Tulandi T. Treatment of uterine fibroids. Is surgery obsolete? N Engl J Med 2007; 25: 411-3.

16. Walker WJ, McDowell SJ. Pregnancy after uterine artery embolization for leiomyomata: a series of 56 completed pregnancies. Am J Obstet Gynecol 2006; 195: 1266-71.

17. Pron G, Mocarski E, Bennett J, et al. Pregnancy after uterine artery embolization for leiomyomata: the Ontario multicenter trial. Obstet Gynecol 2005; 105: 67-76.

18. Pietura R, Jakiel G, Swatowski D, et al. Pregnancy 4 months after uterine artery embolization. Cardiovasc Intervent Radiol 2005; 28: 117-9.

19. Mais V, Ajossa S, Guerriero S, et al. Laparoscopic versus abdominal myomectomy: a prospective randomised trial to evaluate benefits in early outcome. Am J Obstet Gynecol 1996; 174: 654-8.

20. Cagnacci A, Pirillo D, Malmusi S, et al. Early outcome of myomectomy by laparotomy, minilaparotomy and laparoscopically assisted minilaparotomy. A randomized prospective study. Hum Reprod 2003; 18: 2590-4.

21. Seracchioli R, Rossi S, Govoni F, et al. Fertility and obstetric outcome after laparoscopic myomectomy of large myomata: a randomized comparison with abdominal myomectomy. Hum Reprod 2000; 15: 2663-8.

22. Dubuisson JB, Fauconnier A, Fourchotte V, et al. Laparoscopic myomectomy: predicting the risk of conversion to an open procedure. Hum Reprod 2001; 16: 1726-31.

23. Pawtowicz PS, Ajdacka U. The role of laparoscopy in the surgical treatment of endometrial cancer. Videosurgery Miniinv 2015; 10: 44-8.

24. Ceccaroni M, Roviglione G, Pesci A, et al. Total laparoscopic hysterectomy of very enlarge uterus (3030 g): case report and review of literature. Videosurgery Miniinv 2014; 9: 302-7.

25. Dubuisson JB, Chapron C, Chavet X, et al. Fertility after laparoscopic myomectomy of large intramural myomas: preliminary results. Hum Reprod 1996; 11: 518-22.

26. Friedmann W, Maier RF, Luttkus A, et al. Uterine rupture after laparoscopic myomectomy. Acta Obstet Gynecol Scand 1996; 75: 683-4.

27. Harris WJ. Uterine dehiscence following laparoscopic myomectomy. Obstet Gynecol 1992; 80: 545-6.

28. Fagotti A, Fanfani F, Ercoli A, et al. Minilaparotomy for type II and III radical hysterectomy: technique, feasibility, and complications. Int J Gynecol Cancer 2004; 14: 852-9.

29. Hoffman M, Lynch C. Minilaparotomy hysterectomy. Am J Obstet Gynecol 1998; 178: 316-20.
30. Kohama T, Hashimoto S, Ueno H, et al. A technique of minilaparotomy-assisted vaginal hysterectomy. Obstet Gynecol 1997; 89: 127-9.

31. Benedetti-Panici P, Meneschi F, Cutillo G, et al. Surgery in minilaparotomy in benign gynecologic disease. Obstet Gynecol 1996; 87: 456-9.

32. Kidan K, Azeze B, Ismail S. Female sterilisation throught mini-laparotomy at Gondar Collage of Medical Sciences. East Afr Med J 2001; 78: 414-7.

33. Kulier B, Boulvain M, Walker D, et al. Minilaparotomy and endoscopic techniques for tubal sterilization. Cochrane Database Syst Rev 2004; 3: CD001328.

34. Lin J, Gu Y, Hua K, et al. Comparative study of laparoscopically assisted mymomectomy and mini-laparatomy for uterine intramural fibroids. Zhonghua Yi Xue Za Zhi 2002; 82: 883-6.

35. Nezhat C, Nezhat F, Bess O, et al. Laparoscopically assisted myomectomy: a report of a new technique in 57 cases. Int J Fertil Menopausal Stud 1994; 39: 39-44.

36. Malinowski A, Matyszewski A, Bartosiak-Majcher I, et al. Assesment of selected parameters depending on the size of abdominal wall incision in patients subjected to minilaparotomy due to benign gynaecological diseases. Ginekol Pol 2008; 79: 192-7.

37. Buttram VC Jr, Reiter RC. Uterine leiomyomata: etiology, symptomatology, and management. Fertil Steril 1981; 36: 433-45.

38. Bernardi TS, Radosa MP, Weisheit A, et al. Laparoscopic myomectomy: a 6-year follow-up single-center cohort analysis of fertility and obstetric outcome measures. Arch Gynecol Obstet 2014; 290: 87-91.

39. Benassi L, Marconi L, Benassi G, et al. Minilaparotomy vs laparotomy for uterine myomectomies: a randomized controlled trial. Minerva Gynecol 2005; 57: 159-63.

40. Pelosi M 2nd, Pelosi M 3rd. Pelosi minilaparotomy hysterectomy: a non-endoscopic minimally invasive alternative to laparoscopy and laparotomy. Surg Technol Int 2004; 13: 157-67.

41. Tinelli A, Mettler L, Malvasi A, et al. Impact of surgical approach on blood loss during intracapsular myomectomy. Minim Invasive Ther Allied Technol 2014; 23: 87-95.

42. Dubuisson JB, Chapron C, Levy L. Difficulties and complications of laparoscopic myomectomy. J Gynecol Surg 1996; 12: 159-65.

43. Sharma J, Wadhwa L, Malhotra M, et al. Minilaparotomy versus conventional laparotomy for abdomonal hysterectomy: a comperative study. Indian J Med Sci 2004; 58: 196-202.

44. Glasser M. Minilaparotomy myomectomy: a minimally invasive alternative for the large fibrioid uterus. J Minim Invasive Gynecol 2005; 12: 275-83.

45. Flynn MK, Niloff JM. Outpatient minilaparotomy for ovarian cysts. J Reprod Med 1999; 44: 399-404.

Received: 14.05.2015, accepted: 14.11.2015. 